\title{
An Empirical Study on the Success Factors of Supplier-Distributor Relationships
}

\author{
Eric $\mathrm{Ng}$ \\ University of Southern Queensland \\ E-Mail: eric.ng@usq.edu.au
}

\begin{abstract}
This study investigates the factors that affect the success of supplier-distributor relationships in the Australian agribusiness industry. While B2B relationships have been researched extensively and across a range of industries, there is little evidence of its application to the agribusiness sector. A preliminary framework of success factors was developed from the extant literature, and investigated through 20 in-depth interviews conducted with 10 agribusinesses from a dyadic perspective. The findings of this research confirmed the initial 11 factors presented in the preliminary framework as being important to the success of supplier-distributor relationships. The research findings also revealed insights into six new factors that were considered to be crucial to the relationship success, which were included in the revised framework for future investigation.
\end{abstract}

Keywords: Supplier-Distributor Relationships, Business-to-Business Relationships, Success Factors, Agribusiness, Australia

\section{INTRODUCTION}

Agribusiness has traditionally been a challenging and competitive industry. Recent natural disasters (e.g. earthquakes, flooding) and economic instability have led to significant changes in the market conditions across the industry and cost pressures are building up on agribusinesses. While the current situation may not be favorable to many agribusinesses, they need to remain competitive. For this reason, many agribusinesses rely on fewer but more efficient and reliable business partners that are willing to establish long-term sustainable relationships in which they can seek 
complementary resources, create synergy and add value to their respective business.

While business-to-business (B2B) relationships has been investigated extensively in the last decade ( $\mathrm{Ng}$, 2010; Andersen and Kumar, 2006; Rauyruen and Miller, 2007; Caceres and Paparoidamis, 2007), there has been a lack of research into the effects of these changes in agribusiness. Limited studies (Wilson, 1995; Bagdoniene and Zilione, 2009; Eid, Trueman, and Ahmed, 2002) have evaluated the success factors for developing B2B relationships, particularly from a dyadic perspective between supplier and distributor within the agribusiness industry. Therefore, the purpose of this paper is to investigate the current long-term relationships from both sides of the dyad by exploring the factors that contribute to their successful development of supplier-distributor relationships. This study draws from both the theory and the preliminary empirical knowledge acquired from interviewing stakeholders who are directly involved in the development of supplier-distributor relationships in the Australian agribusiness industry. Thus, this exploratory research will seek to address the question 'What are the success factors in supplier-distributor relationships? Why?' The research findings seek to contribute towards the B2B relationships theory in the supplier-distributor context by exploring new insights and also with the confirmation or disconfirmation of the factors identified in the literature. In addition, the findings can provide practical contributions that are beneficial to agribusiness managers where they can enhance their competitiveness in the industry through the development of sustainable supplier-distributor relationships.

This paper begins by reviewing the literature relevant to the research issue and then discusses the methodology adopted in researching this issue. Next, the research findings are presented, followed by the conclusions drawn from the research, the implications from these, and finally suggestions for further research.

\section{LITERATURE REVIEW}

The development of B2B relationships are often based on variables such as experience, uncertainty, co-operation, commitment and mutual adaptation, and this itself is complex in its own nature (Ford, 1980). B2B relationships refer to the relation established between two or more businesses which are characterized by three dimensions: activity links, actor bonds and resources ties (Ford et al., 1998; Hakansson and Snehota, 1995; Hakansson and Johanson, 1992). The dimension of activity links relate to the technical, administrative, commercial and other activities that businesses can connect in different ways (Hakansson and Snehota, 1995). The second dimension, actor bonds, seeks to connect actors and influence how they 
perceive and evaluate each other and form their opinions in relation to one another (Hakansson and Snehota, 1995; Steffens and Matthews, 2004). The third dimension, resources ties, relates to the connection of different resource elements (technological, material, knowledge resources and other intangibles) (Hakansson and Snehota, 1995; Steffens and Matthews, 2004).

The success of B2B relationships can be determined by two distinctive approaches: objective measure (e.g. sales volume), and soft measure (e.g. service quality). The objective measure approach seeks quantifiable measurements of the mutual benefits that businesses can attain from the relationships (Dibbern, Goles, Hirschheim, and Jayatilaka, 2004; Tuten and Urban, 2001). In contrast, the soft measure approach is associated to the business partners' overall level of positive satisfaction and meeting performance expectations (Bagdoniene and Zilione, 2009; Eid et al., 2002; Tuten and Urban, 2001). Regardless of the approach undertaken, B2B relationships are regarded as successful when the business goals have been achieved, thus creating or adding value to the stakeholders (e.g. customers, employees).

The literature posits four types of B2B relationships (sellers-buyers, manufacturers-dealers, providers-consumers, and suppliers-distributors) that are developed over a period of time. Such a relationships requires more than just monetary transactions and should include other activities (including commitments and resources) that contribute to a sustainable long-term relationship (Axelsson and Easton, 1992; Narayandas and Rangan, 2004; Ganesan, 1994). While the literature included extensive empirical investigation into the success factors of developing sustainable B2B relationships in several industries (such as manufacturing and software) (Caceres and Paparoidamis, 2007; Cann, 1998; Kingshott and Pecotich, 2007; Jones, Taylor, and Bansal, 2009), there is limited evidence of such studies conducted specifically on supplier-distributor relationships in the agribusiness industry (which is the focus of this study).

Based on the literature reviewed, a preliminary framework (Figure 1) was developed from these previous studies on B2B relationships, which had investigated different success factors. Each of these factors will be addressed in turn. 


\section{Time dimension}

- Commitment

- Loyalty

- Trust

- Closeness

- Involvement

- Satisfaction

- Information exchange*

- Product/service quality*

\section{Structure dimension}

- Flexibility

- Negotiation

\section{Process dimension}

- Adaptation

- Cooperation

- Social bonds

- Non-retrievable investments*

\section{dimension* \\ - Mutual goals* \\ - Joint working*}

Substance \& functions

\section{Value dimension*}

- Knowledge value*

Figure 1 Preliminary Framework for Developing Sustainable Supplier-Distributor

\section{Relationships}

Adapted from: Bagdoniene and Zilione, 2009; Ford, 1980; Castro, Alves, and Proenca, 2005; Lian and Laing, 2007; Dwyer, Schurr, and Oh, 1987; Schmidt, Tyler, and Brennan, 2007; Powers and Reagan, 2007

Note: Based on the case study findings, factors and dimensions with a $(*)$ were added to the framework as important to the success of supplier-distributors relationships. 
- Time dimension

B2B relationships are dynamic and are seen as evolutionary processes to increase the experience of businesses involved, minimize uncertainty in the relationship, develop both actual and perceived commitment, and develop formal and informal adaptations and increase investment and savings involved in such a relationship (Ford, 1980). The time dimension provides a timeframe boundary for which B2B relationships are developed through the interaction and learning from one another and the mutual involvement in a range of activities at different stages of the process (Medlin, 2004). While studies have shown the diversity of the B2B relationships development stages, there are common factors that contribute to the successful development of supplier-distributor relationships.

The literature suggested that commitment plays a critical role in determining between 'stayers and leavers' where such commitments to the learning processes and investments are evident to the continuity of the valued relationship (Ford, 1980; Dwyer et al., 1987; Handfield and Bechtel, 2002; Mummalaneni, 1987). Furthermore, commitments can ensure future value and benefits to businesses that are involved in the relationship (Caceres and Paparoidamis, 2007; Hardwick and Ford, 1986). Loyalty shown by the business partners plays an essential role in the success of $\mathrm{B} 2 \mathrm{~B}$ relationships, and this is particularly true in the later stages (long-term and final stages) of the relationship development process (Rauyruen and Miller, 2007; Bagdoniene and Zilione, 2009). The likelihood of continuing the B2B relationship is greatly affected by the loyalty and commitment displayed by the business partners so that increasing commitments, adaptations and interactions can be achieved (Caceres and Paparoidamis, 2007).

\section{- Trust}

Trust is another factor that is important to the success of a B2B relationship, and this is particularly significant in the relationship development stage. Trust encourages open communication, exchange of ideas/knowledge, and sharing of resources between business partners that improve the relationship (Cowles, 1996). The level of trust between business partners also serves as a key indicator of the continuity of the relationship and their success (Sharma and Patterson, 1999; Doney and Cannon, 1997; Kramer and Tyler, 1995).

Findings from previous studies (Ford, 1980; Dwyer et al., 1987; Nielson, 1998) revealed that closeness and involvement can enhance the stability and sustainability of relationships. The confidence about the relationships can be enhanced when a close working relationship between business partners is established with extensive 
involvement (Ford, 1980; Hess, Fannin, and Pollom, 2007). The strengthening of the relationships is often demonstrated by increasing cooperation and involvement, mutual problem solving and adaptations.

- Satisfaction

Satisfaction with the B2B relationships is important as it advances the development of trust and commitment, which contribute towards achieving relationship success through better retention of business customers, increasing sales and meeting expectations (Rauyruen and Miller, 2007; Powers and Reagan, 2007). Thus, a high level of mutual satisfaction is crucial to the maintenance of sustainable relationships.

\section{- Structure dimension}

Business relationship structures are the characteristics that can be easily observed by outsiders. There are four key features: continuity, complexity, symmetry and informality that are relevant to the relationship structure (Castro et al., 2005). Previous studies (Bagdoniene and Zilione, 2009; Ferrer-Balas and Buckland, 2008) suggested that the level of flexibility that business partners bring into the relationships can have an impact on its success. Flexibility provided by business partners has a positive effect on the relationship development which can encourage coordination and interaction between businesses to achieve mutual goals (Gittell, 2006; Davis and Walker, 2007). On the other hand, the continuity of business relationships can also be affected by negotiation as businesses attempt to reach decisions and agreements on disputable issues (Weigand, Moor, Schoop, and Dignum, 2003).

\section{- Process dimension}

The process associated with the development of B2B relationships is often complicated, so businesses need to consider the relevant aspects of adaptation, cooperation and social bonds. The literature (Bagdoniene and Zilione, 2009; Hallen, Johanson, and Seyed-Mohamed, 1991) revealed that adaptations tend to bond business partners into a closer relationship and are signs of willingness to seek improvements on the existing business relationships. Furthermore, adaptations may also imply considerable investments by the business partners where such investments are often specific to the relationship and are not transferable (Schmidt et al., 2007; Woo and Ennew, 2004). 


\section{- Effective cooperation}

Effective cooperation between business partners increases the potential for success in $\mathrm{B} 2 \mathrm{~B}$ relationships. Business partners that are prepared to make cooperative changes demonstrate their commitment and willingness to develop and maintain on-going relationships (Woo and Ennew, 2004). In addition, successful business relationships also require cooperative behaviors from business partners to undertake joint tasks and activities in order to pursue common goals (Wilson and Nielson, 2001; Mohr and Spekman, 1994). Business partners with strong social bonds are more committed to maintaining the relationship and thus more sustainable (Biggemann and Buttle, 2004; Mummalaneni and Wilson, 1991). Moreover, social bonds bring business partners closer together on a personal level through interactivity and the exchange of knowledge and skills, which contributes to the success of $\mathrm{B} 2 \mathrm{~B}$ relationships (Gefen, 2004; Ng, 2009; Stanko, Bonner, and Calantone, 2007).

\section{RESEARCH METHODOLOGY}

This research was exploratory in nature and had adopted the case study methodology, which assisted in confirming or disconfirming the success factors in the preliminary framework, as identified in the literature reviewed (Parkhe, 1993; Yin, 2003). The adoption of the case study approach is justified on the following bases. Firstly, case study research focuses on an organization or industry to rigorously explore and analyze the contemporary real-life experiences and events while retaining the holistic and meaningful characteristics of these experiences and events. This captures the richness and depth of contextual meaning (such as the reasoning of the success factors for supplier-distributor relationships) that can lead to new insight (Yin, 2003). Next, the approach undertaken by this research focuses on exploring the complexity and dynamism of the context within the organizational settings and events such as the success factors for B2B relationships in the Australian agribusiness industry (Yin, 2003; Perry, 1998; Carson, Gilmore, Perry, and Gronhaug, 2002). Thirdly, case study research provides a more informed basis for theory building than surveys and is deemed suitable to new research areas or research areas where the existing theory seems inadequate (Yin, 2003; Eisenhardt, 1989; Patton, 1990). As evident in this research, there are limited research studies in this area, particularly in the Australian agribusiness industry context. Through case studies, this research will attempt to investigate the complex business environment in the agribusiness industry that provides a real-life account of the research issue raised and builds on theory for further conclusive research. 
Ten cases within the agribusiness industry were selected judgmentally based on the criteria that they have operated in the industry for a minimum of five years and have on-going business relationships with the partner (supplier or distributor) for at least three years. These 10 cases were equally represented by five supplying and distributing organizations respectively. For each case, two interviews were conducted with the executive director or equivalent (who is involved in managerial activities) and a middle level manager or operational staff (who is involved in the daily operational activities), to determine if significant differences existed between (1) management versus operations perspectives and (2) supplier versus distributor perspectives.

In this research, replication logic in multiple case studies was used to achieve external validity. The construct validity of this study was achieved with the use of multiple sources of evidence through secondary sources (such as the company's business plans, marketing plans and other relevant documentations), which were used to further triangulate the results. These interviews were semi-structured, flexible and informal, which provided a greater sensitivity to misunderstanding by interviewees and also revealed in-depth understanding about feelings and emotions toward the specific factors relevant to the success of supplier-distributor relationships. A case study protocol was developed and used throughout the interviewing process to enhance the reliability of the study and to ensure all relevant issues were consistently addressed and conveyed to the interviewees. Each in-depth interview lasted approximately 60 minutes.

\section{Data Analysis}

This research adopted content analysis procedures that began with the coding of themes in the interview questions (Berg, 1995; Miles and Huberman, 1994; Neuman, 1994). In this analysis, data in each interview was coded in terms of the actual questions on the interview protocol, which could assist in revealing relationships and new ideas or areas for coding (Berg, 1995; Neuman, 1994). The coded interviewing questions within each interview were then compared and contrasted to identify the major issues and derive some form of generalization (Berg, 1995; Neuman, 1994). In addition, narrative text and quotations from case studies were used to enhance the credibility of data analysis and to add qualitative insights to the research issues (Patton, 1990). The findings of this research will be discussed in the next section. 


\section{RESULTS}

A total of 20 in-depth interviews were conducted with 10 agribusinesses (5 supplying organizations and 5 distributing organizations) where 15 of the interviewees were male and the remaining 5 were female. Eighteen of the 20 interviewees had more than 5 years of experience in the agribusiness industry, while other interviewees had at least 2 years of relevant experience. All interviewees had direct involvement in activities related to the development of business relationships. A summary of the interviewees' profile is presented in Table 1.

Table 1 Profiles of the Interviewees

\begin{tabular}{|c|c|c|c|}
\hline $\begin{array}{c}\text { Case / } \\
\text { Interviewee }\end{array}$ & Position / Gender & $\begin{array}{c}\text { Years of agribusiness } \\
\text { experiences }\end{array}$ & $\begin{array}{c}\text { Organisation } \\
\text { type }\end{array}$ \\
\hline A1 & General manager (Male) & 12 & Supplying \\
\hline $\mathrm{A} 2$ & Sales manager (Male) & 7 & Supplying \\
\hline B1 & Managing director (Male) & 15 & Supplying \\
\hline $\mathrm{B} 2$ & Marketing manager (Male) & 6 & Supplying \\
\hline $\mathrm{C} 1$ & Director (Male) & 8 & Supplying \\
\hline $\mathrm{C} 2$ & $\begin{array}{l}\text { Accounts executive } \\
\text { (Female) }\end{array}$ & 3 & Supplying \\
\hline D1 & Partner (Female) & 15 & Supplying \\
\hline D2 & $\begin{array}{l}\text { Client service manager } \\
\text { (Male) }\end{array}$ & 10 & Supplying \\
\hline E1 & Owner (Female) & 11 & Supplying \\
\hline E2 & Business manager (Male) & 7 & Supplying \\
\hline $\mathrm{F} 1$ & Operation director (Male) & 22 & Distributing \\
\hline $\mathrm{F} 2$ & $\begin{array}{l}\text { Customer service executive } \\
\text { (Female) }\end{array}$ & 2 & Distributing \\
\hline G1 & Executive director (Male) & 19 & Distributing \\
\hline $\mathrm{G} 2$ & Operations manager (Male) & 20 & Distributing \\
\hline H1 & Managing director (Male) & 14 & Distributing \\
\hline $\mathrm{H} 2$ & Senior purchaser (Male) & 6 & Distributing \\
\hline I1 & General manager (Male) & 17 & Distributing \\
\hline $\mathrm{I} 2$ & $\begin{array}{l}\text { Purchasing manager } \\
\text { (Female) }\end{array}$ & 13 & Distributing \\
\hline $\mathrm{J} 1$ & Owner (Male) & 9 & Distributing \\
\hline $\mathrm{J} 2$ & Marketing manager (Male) & 6 & Distributing \\
\hline
\end{tabular}


Interviewees consistently agreed that all 11 factors identified in the literature were important to the success of supplier-distributor relationships. The results also revealed insights to 6 new factors that could have a significant impact on the development of sustainable supplier-distributor relationships: (1) information exchange, (2) product/service quality, (3) non-retrievable investments, (4) mutual goals, (5) joint working, and (6) knowledge value. A summary of the results from the case studies is presented in Table 2.

Table 2 Summary results from the case studies

\begin{tabular}{ll}
\hline \multicolumn{1}{c}{ Success factors } & No. of interviewees mentioned the factor \\
\hline Time dimension & 20 \\
\hline Commitment & 20 \\
\hline Trust & 19 \\
\hline Satisfaction & 19 \\
\hline Loyalty & 15 \\
\hline Closeness & 15 \\
\hline Involvement & 15 \\
\hline Information exchange* & 12 \\
\hline Product/service quality* & 18 \\
\hline Structure dimension & 16 \\
\hline Flexibility & 19 \\
\hline Negotiation & 18 \\
\hline Process dimension & 16 \\
\hline Adaptation & 13 \\
\hline Social bonds & 15 \\
\hline Cooperation & \\
\hline Non-retrievable investments* & 16 \\
\hline Substance and functions dimension & \\
\hline Mutual goals* & \\
\hline Joint working* & \\
\hline Value dimension & \\
\hline Knowledge value* & \\
\hline Source: field data collected for this research & \\
Note: where factors have similar score in the column total, they will be discussed in order from time \\
\hline \multicolumn{1}{l}{ dimension to value dimension as they appear in this table. } \\
\hline
\end{tabular}


All interviewees agreed that commitment and trust were critical to the success of supplier-distributor relationships. A high level of commitment gave confidence and assurance to suppliers and distributors that they were capable of fulfilling their obligations. This was supported by an interviewee stating that "To us, their (distributors) long time commitment is the assurance for our success (business relationships)". Commitment towards the relationships was also seen as a sign of trust to the business partners, which was only evident in the later stages of the relationship development process. In supporting this, one interviewee commented that "A genuine relationship requires commitment and trust. However, this takes time to come into effect. For us, this has taken 12 years of working with our suppliers, and now we have utmost trust in one another".

Satisfaction and loyalty were regarded as key factors for the development of sustainable business relationships. Interviewees indicated that the level of satisfaction could impact the continuity of a supplier-distributor relationship and also served as a basis for establishing a long-term loyal business partnership. For example, a high level of relationship satisfaction can reduce the intensity of negative emotions (e.g. accusation, anger) which could have damaged the relationships significantly. One interviewee supported this by commenting that "Over the years, we have satisfactory relationships with our distributors and in my opinion there isn't any issue or problem that we cannot resolve together. We are committed to help one another and often put our differences aside for the benefits of our long established relationship". Interviewees also agreed that adaptation could play a major role in the success of their supplier-distributor relationships. They believed that being able to accommodate the needs of the business partners was a sign of their willingness to help strengthen their relationships. This was supported by an interviewee stating that "We make adaptations to our ordering and delivery system so that it fits with the supplier's procedures. We showed goodwill in this and they do appreciate what we have done".

Interviewees also acknowledged that flexibility was essential to the success of developing supplier-distributor relationships. It was evident that suppliers and distributors gave preference to business partners that were flexible in meeting their needs and this would have increased their interaction that led to a further development in their relationships. An interviewee supported this by commenting "Being flexible in ways that we conduct our business has allowed us to develop a stronger relationship with our suppliers". Social bonds had been regarded by the interviewees as crucial to their supplier-distributor relationships since many benefits (e.g. tacit knowledge and skills) could be gained from the social exchanges. This was supported by an 
interviewee commenting "The invaluable knowledge that I have acquired over the years from my suppliers made me realize how important this relationship is not just to me but also to our business".

Negotiation, cooperation, mutual goals and knowledge value were highlighted as important success factors for supplier-distributor relationships. Effective negotiation was considered by the interviewees as a means to develop a longer-term relationship with their business partners, and they also acknowledged that if it was poorly managed, it would destroy the business relationships. They believed that business negotiation should aim to have a compromise agreement that enables on-going business relationships. This was supported by an interviewee stating that "We go into any business negotiation with the view that all parties should be treated fairly and come to an agreement that is generally satisfactory for all. This ensures that the business relationships can be continued. Repeat business is good business to us".

Interviewees argued that cooperative behavior (e.g. joint problem solving) could contribute to sustainable business relationships. Through cooperation, business partners were able to work more closely and gain a better understanding of one another whereby mutual benefits (e.g. increase profit) could be achieved. Cooperation was regarded as an indication of the level of commitment towards the relationships. For example, a high level of cooperation in product innovation between the supplier and distributor shows a strong relationship that had been successful over many years.

Interviewees revealed that mutual goals were often accomplished through joint efforts between the business partners, and provided a strong reason for the continuity of the relationships. It was also agreed that mutual goals brought and held the relationships together where a common understanding of expectations existed. In contrast, the lack of understanding towards mutual goals could give rise to potential conflicts and caused damage to the relationships. One interviewee commented "Knowing that we shared in common will definitely help in improving the relationships".

Many agribusinesses in Australia emphasized the importance of knowledge value since it could improve their competitiveness in the competitive industry. Interviewees agreed that the sharing of knowledge (e.g. market intelligence, new product ideas) between the suppliers and distributors had enhanced the strategic value of their business relationships. In supporting this, an interviewee commented "Our distributors regularly share with us the market information on what our end user customers think about our products and how we can further improve them to better meet their (end user customers) needs. I must say this has been a key to our successful 
relationships".

The interviewees considered closeness, involvement, information exchange, and joint working to be important factors in the success of supplier-distributor relationships. For example, business relationships that were characterized by close and highly involved working relationships were often seen as evidence of stability and confidence in the relationship. For example, one interviewee stated that "We work very closely with our suppliers and get involved in different activities such as promotion and annual planning events. This helps to build a strong relationship".

On the other hand, interviewees believed that the sharing of information could give them a better understanding of their partners and achieve mutual benefits. For example, synergy could be achieved with suppliers and distributors sharing information about their key strengths so that values could be further added to the end customers.

Joint working and planning of activities were indications of a close bond and understanding between suppliers and distributors. While the interviewees agreed that joint working (e.g. through mutual decision-making and problem identification and solving) could at times be difficult to coordinate because of the differing levels of commitments that each partner had, through communication and accommodation such joint involvements could be achieved and developed into sustainable relationships. An interviewee who supported this commented "Initially joint planning of activities is difficult, but when we see the benefits from such joint efforts, we realized how important this is to our relationships with the distributors".

Non- retrievable investments were highlighted by the interviewees as a factor that could impact on the success of supplier-distributor relationships. For example, business partners that had invested specific resources (such as capital improvements, training, equipment and software) into a relationship would be highly valued as a significant contributor to the building of stronger social and structural bonds between the suppliers and distributors.

Interviewees also suggested product/service quality as an important factor that could affect the success of the relationships. Product and service quality have had great impact on the level of satisfaction by the business partners, which could result in the continuity or termination of the relationships. For example, distributors in the agribusiness industry tend to rely on their suppliers to provide the technical support for their products, so suppliers that failed to provide adequate service could easily damage the business relationships and thus encourage the distributors to discontinue the relationships. 
The results highlighted 6 new factors that were considered as important to the success of supplier-distributor relationships: information exchange, product/service quality, non-retrievable investments, mutual goals, joint working, and knowledge value. These new insights could be attributed to the nature of the case study's business and also the differing cultures in the Australian agribusiness industry.

\section{Differences in Response}

The findings suggested that there were differences in responses for 2 (non-retrievable investments and product/service quality) of the 17 success factors based on management versus operational perspectives. Management interviewees believed that business partners would make non-retrievable investments into the relationships only if they had considered it to be strong, successful to date and that the relationships had been stably established over a period of time. It was also noted that such a type of managerial decision often requires substantial time and considerations to the many different aspects of the business as a whole to determine if such investments were worthwhile. This was supported by an interviewee stating "This (non-retrievable investment) is no easy decision to make since it can involve significant investments. But it will be the right decision to make when we see that the relationship has progressed very positively over the years. Making such commitments will only further enhance our relationships and advanced it to the next level". In contrast, operational interviewees might not appreciate the importance of non-retrievable investments to the success of supplier-distributor relationships because they had limited understanding and involvement in such investments. An interviewee supported this with the comment "I have no involvement in this (non-retrievable investments) and don't see how this can really affect the success of the relationships".

On the other hand, interviewees from operational roles indicated that product/service quality could essentially affect their views about the continuity of the relationships. For example, frequent complaints received by the operational staff from the customers about poor product quality could cause significant inconvenience to them (such as having to respond to customers complaints, organize replacement of faulty products). As a result, negative impressions about the suppliers could be developed and therefore damaging the relationships.

The study found no major differing opinions between interviewees from supplying and distributing organizations with regards to the factors impacting on the success of supplier-distributor relationships. 


\section{CONCLUSIONS, CONTRIBUTIONS AND LIMITATIONS}

In conclusion, 20 in-depth interviews were conducted with 10 agribusinesses in Australia. The interviewees highlighted a list of 17 factors that were considered to be important to the success of supplier-distributor relationships. The findings supported the initial 11 factors identified in the preliminary framework and also revealed 6 new factors that could be crucial to the development of sustainable supplier-distributor relationships: information exchange, product/service quality, non-retrievable investments, mutual goals, joint working and knowledge value. As a result of new insights acquired, the preliminary framework had been revised to include the new factors identified and was also incorporated into categories based on the 5 dimensions of B2B relationships in the literature: time, structure, process, substance and functions, and value. From this study, agribusiness managers were provided with a list of success factors that they could take into consideration (according to their differing situations) when developing sustainable supplier-distributor relationships. This will enable mutual benefits and improve competitiveness in the agribusiness industry.

This study investigated the supplier-distributor relationships in Queensland, Australia, and therefore the findings could not be generalized to other geographical areas and/or the population at large. To allow generalization, future studies could look at a more representative sampling population and be tested. Further studies could also investigate other industries and countries to provide comparisons and determine their similarities and differences.

\section{REFERENCES}

Andersen, P. H. and Kumar, R. (2006). Emotions, trust and relationship development in business relationships: A conceptual model for buyer-seller dyads. Industrial Marketing Management, 35(4), 522-535.

Axelsson, B., and Easton, G. (1992). Industrial networks: A new view of reality. London: Routledge.

Bagdoniene, L. and Zilione, R. (2009). Business to Business Relationships: The Variables in the Context of Success. Social Sciences, 4(66), 16-25.

Berg, B. L. (1995). Qualitative Research Methods for Social Sciences. Boston: Allyn \& Bacon.

Biggemann, S. and Buttle, F. (2005). Conceptualising Business-to-Business Relationship Value. Proceedings of the $21^{\text {st }}$ Industrial Marketing and Purchasing Group Conference, September 1-3, 2005, Rotterdam, Netherlands. 
Caceres, R. C. and Paparoidamis, N. G. (2007). Service quality, relationship satisfaction, trust, commitment and business-to-business loyalty. European Journal of Marketing, 41(7), 836-867.

Cann, C. W. (1998). Eight steps to building a business-to-business relationship. Journal of Business and Industrial Marketing, 13(4), 393-405.

Carson, D., Gilmore, A., Perry, C. and Gronhaug, K. (2002). Qualitative marketing research. London: Sage Publications.

Castro, L. M., Alves, G. A. and Proenca, J. F. (2007). The Key Dimensions in the Development of the Consultant-Client Relationship: a Suggestion for a Business Relationship Profile, Proceedings of the 3rd IMP-Asia Conference, December 9-12, 2007, Phuket, Thailand.

Cowles, D. L. (1996). The role of trust in customer relationships: asking the right questions. Management Decision, 35(4), 273-282.

Davis, P. R. and Walker, D. H. T. (2007). Trust, commitment and mutual goals in Australian construction industry project alliances. In D. Walker and S. Rowlinson (Eds.), Procurement systems - a cross-industry project management perspective (pp. 378-399). London: Taylor \& Francis.

Dibbern, J., Goles, T., Hirschheim, R. and Jayatilaka, B. (2004). Information Systems Outsourcing: A Survey and Analysis of the Literature. Database of Advances in Information Systems, 35(4), 6-102.

Doney, P. M. and Cannon, J. P. (1997). An examination of the nature of trust in buyer-seller relationships. Journal of Marketing, 61(2), 35-51.

Dwyer, R. F., Schurr, P. H. and Oh, S. (1987). Developing buyer-seller relationships. Journal of Marketing, 51(2), 11-27.

Eid, R., Trueman, M. and Ahmed, A. M. (2002). A cross-industry review of B2B critical success factors. Internet Research, 12(2), 110-123.

Eisenhardt, K. (1989). Building theory from case study research. Academy of Management Review, 14(4), 532-550.

Ferrer-Balas, D. and Buckland, H. (2008). Mutual learning for sustainability. International Journal of Sustainability in Higher Education, 9(4), 450-468.

Ford, D. (1980). The development of buyer-seller relationships. European Journal of Marketing, 14(5/6), 339-354.

Ford, D., Gaddle, L. E., Hakansson, H., Lundgren, A., Snehota, I., Turnbull, P. and Wilson, D. (1998). Managing business relationships. Chichester: John Wiley and Sons. 
Ganesan, S. (1994). Determinants of long-term orientation in buyer-seller relationships. Journal of Marketing, 58(2), 1-19.

Gefen, D. (2004). What Makes an ERP Implementation Relationship Worthwhile: Linking Trust Mechanisms and ERP Usefulness. Journal of Management Information Systems, 21(1), 263-288.

Gittell, J. H. (2006). Relational coordination: Coordinating work through relationships of shared goals, shared knowledge and mutual respect. In O. Kyriakidou and M. F. Ozbilgin (Eds.), Relational perspectives in organizational studies - a research companion (pp. 74-94). Cheltenham: Edward Elgar.

Hakansson, H. and Johanson, J. (1992). A Model of Industrial Networks. In D. Ford (Ed.), Understanding Business Markets. (2nd Edition) (pp. 129-135). London: Thomson Learning.

Hakansson, H. and Snehota, I. (1995). Analysing Business Relationships. In D. Ford (Ed.), Understanding Business Markets. (2nd Edition) (pp. 151-175). London: Thomson Learning.

Hallen, L., Johanson, J. and Seyed-Mohamed, N. (1991). Inter-firm Adaptation in Business Relationships. Journal of Marketing, 55(April), 29-37.

Handfield, R. B. and Bechtel, C. (2002). The role of trust and relationship structure in improving supply chain responsiveness. Industrial Marketing Management, 31(4), 367-382.

Hardwick, B. and Ford, D. (1986). Industrial Buyer Resources and Responsibilities and the Buyer-Seller Relationships. Industrial Marketing and Purchasing, 1(1), 3-25.

Hess, J. A., Fannin, A. D. and Pollom, L. H. (2007). Creating closeness: Discerning and measuring strategies for fostering closer relationships. Personal Relationships, 14(1), 25-44.

Jones, T. D., Taylor, S. F. and Bansal, H. S. (2009). Targets of commitment in service provider-consumer relationships: a prototyping study. Qualitative Market Research: An International Journal, 12(1), 36-48.

Kingshott, R. P. J. and Pecotich, A. (2007). The impact of psychological contracts on trust and commitment in supplier distributor relationships. European Journal of Marketing, 41(9), 1053-1072.

Kramer, R. M. and Tyler, T. R. (1995). Trust in Organizations: Frontiers of Theory and Research. Thousand Oaks, CA: Sage Publications. 
Lian, P. C. S. and Laing, A. W. (2007). Relationships in the purchasing of business to business professional services: The role of personal relationships. Industrial Marketing Management, 36(6), 709-718.

Medlin, C. J. (2004). Interaction in business relationships: A time perspective. Industrial Marketing Management, 33(3), 185-193.

Miles, M. B. and Huberman, A. M. (1994). Qualitative Data Analysis: An Expanded Sourcebook. (2nd Edition). Thousand Oaks, CA: Sage Publications.

Mohr, J. and Spekman, R. (1994). Characteristics of Partnership Success: Partnership Attributes, Communication Behavior, and Conflict Resolution Techniques. Strategic Management Journal, 15(2), 135-152.

Mummalaneni, V. (1987). The Influence of a Close Personal Relationship Between the Buyer and the Seller on the Continued Stability of Theory Role Relationships. Ph.D. dissertation, Pennsylvania State University, University Park.

Mummalaneni, V. and Wilson, D. T. (1991). The Influence of a Close Personal Relationship Between a Buyer and Seller on the Continued Stability of Their Role Relationship, Working paper 4-1991, The Institute for the Study of Business Markets, Pennsylvania State University, University Park.

Narayandas, D. and Rangan, V. K. (2004). Building and sustaining buyer-seller relationships in mature industrial markets. Journal of Marketing, 68(July), 63-77.

Neuman, W. L. (1994). Social Research Methods: Qualitative and Quantitative Approaches. Boston: Allyn \& Bacon.

$\mathrm{Ng}$, E. (2009). An empirical investigation on the dyad perspective of buyer-seller relationships in Australian regional agribusinesses. Contemporary Management Research, 5(3), 287-300.

$\mathrm{Ng}$, E. (2010). Understanding B2B supplier selection relationships: the case of Taiwan agribusinesses. Journal of Business-to-Business Marketing, 17(2), 149-172.

Nielson, C. C. (1998). An empirical examination the role of "closeness" in industrial buyer-seller relationships. European Journal of Marketing, 32(5), 441-463.

Parkhe, A. (1993). Messy research, methodological predispositions and theory development in international joint venture. Academy of Management Review, 18(2), 227-68.

Patton, M. Q. (1990). Qualitative Evaluation and Research Methods. Newbury Park, CA: Sage Publications.

Perry, C. (1998). Processes of a case study methodology for postgraduate research in marketing. European Journal of Marketing, 32(9), 758-802. 
Powers, T. L. and Reagan, W. R. (2007). Factors influencing successful buyer-seller relationships. Journal of Business Research, 60(12), 1234-1242.

Rauyruen, P. and Miller, K. E. (2007). Relationship quality as a predictor of B2B customer loyalty. Journal of Business Research, 60(1), 21-31.

Schmidt, S. O., Tyler, K. and Brennan, R. (2007). Adaptation in inter-firm relationships: classification, motivation, calculation. Journal of Services Marketing, 21(7), 530-537.

Sharma, N. and Patterson, P. G. (1999). The impact of communication effectiveness and service quality on relationship commitment in consumer, professional services. The Journal of services marketing, 2(9), 151-170.

Stanko, M. A., Bonner, J. M. and Calantone, R. J. (2007). Building commitment in buyer-seller relationships: A tie strength perspective. Industrial Marketing Management, 36(8), 1094-1103.

Steffens, P. and Matthews, J. H. (2004). Network Governance of R\&D: Purchaser-Provider as Partnerships in a Public Sector Agency. British Academy of Management Conference, August 30-Sepetember 2, 2004, St. Andrews: U.K..

Tuten, T. L. and Urban, D. J. (2001). An Expanded Model of Business-to-Business Partnership Formation and Success. Industrial Marketing Management, 30(2), $149-164$

Weigand, H., Moor, A., Schoop, M. and Dignum, F. (2003). B2B Negotiation Support: The Need for a Communication Perspective. Group Decision and Negotiation, 12(1), 3-29.

Wilson, D. T. (1995). An integrated model of buyer-seller relationships. Journal of the Academy of Marketing Science, 23(4), 335-345.

Wilson, E. J. and Nielson, C. C. (2001). cooperation and continuity in strategic business relationships. Journal of Business-to-Business Marketing, 8(1), 1-24.

Woo, K. and Ennew, C. T. (2004). Business-to-business relationship quality. European Journal of Marketing, 38(9), 1252-1271.

Yin, R. K. (2003). Case study research: design and methods. (3rd Edition). Thousand Oaks, CA: Sage Publications. 
